\title{
Chapter 3 \\ Migration Statistics in Europe: A Core Component of Governance and Population Research
}

\author{
Albert Kraler, David Reichel*, and Han Entzinger
}

\subsection{Introduction}

'State' and 'statistics' are not only related etymologically. ${ }^{1}$ Rather, statistics represent a fundamental technique of modern government comparable to the role of law in modern societies. Like law, statistics are about procedure and standardisation. Whereas law is about standardising the exercise of power and (legal) relations amongst citizens, between citizens and the state as well as relations within the state, statistics are about knowledge necessary for such exercise of power and authority. Statistics - in James Scott's famous formulation (Scott 1998) - enable states to 'see'. They bring order to the fluid object that is a population, a territory or other objects of power by standardising and structuring social reality into discrete countable units, thereby (so Scott's Foucauldian argument goes) also transforming populations into governable subjects. Indeed, the history of statistics as a specific field of knowledge production is intricately linked to the history of the modern state and modern \footnotetext{
Agency for Fundamental Rights (FRA) Schmidt 2005).

A. Kraler

ICMPD's Research Unit, Vienna, Austria

D. Reichel

European Union Agency for Fundamental Rights, Vienna, Austria

H. Entzinger $(\bowtie)$

Department of Sociology, Erasmus University Rotterdam, P.O. Box 1738,

3000 DR Rotterdam, Netherlands

e-mail: entzinger@fsw.eur.nl

*The opinions of this author expressed in this chapter do not represent those of the European Union

${ }^{1}$ The word statistics most probably stems from the Italian word statista meaning 'statesman' (cf. 
forms and theories of governance. ${ }^{2}$ Thus, about the same time as Thomas Hobbes published Leviathan, with its famous frontispiece showing the sovereign as made up of people, one of the first more sophisticated endeavours to statistically describe the population was published (see Hacking 2006). Like Hobbes famous picture, population statistics go along with a powerful and suggestive imaginary: statistics sum up a mass of people, thereby also assuming a fundamental 'sameness' of those individuals so summed up, making one population out of many. ${ }^{3}$ In a sense, a population only comes into being as a result of this performative act of (statistically) describing $a$ population. ${ }^{4}$ Yet statistics not only enable the aggregation of individual units into a larger whole (such as individual persons into a population); they also enable one to discern or to differentiate classes of entities within larger wholes. On the general level of total populations, population statistics thus entail the capability to distinguish one population from another. Within individual populations, statistics permit one to distinguish classes of individuals by grouping them according to different characteristics associated with individuals, thus also facilitating the generation of generalisable knowledge about the structure and characteristics of a population. It is this specific knowledge produced by population statistics that provides an entry point for policy intervention. As Espeland and Stevens (2009: 415) put it: 'Seeing something is the first step to controlling it.' 'Seeing something', however, is no simple act. It requires recognition in the literal sense of the term's Latin root, i.e. being able to recognise things through pre-defined categories of difference - which importantly are simultaneously also categories of sameness. Nationality is such a category, as are ethnicity or country of birth; these categories arguably represent the core concepts for ethnic and migration studies.

As Armin Nassehi and Markus Schroer (1999) have argued, nationality was a crucial device for constructing nation states in the wake of the French Revolution. In particular, the invention of nationality as a fundamental legal status responded to the 'need to reconcile the universality of human rights with the particularity of its validity within the context of single nation states' (Nassehi and Schroer 1999: 88). ${ }^{5}$ Nationality was to be constructed for societies that sought integration within the boundaries of nation states but at the same time had to define themselves as different to other nation states. Population statistics were crucial in symbolically achieving this goal. With the rise of nationality as a fundamental legal category during the nineteenth century nationality also became increasingly important as a

\footnotetext{
${ }^{2}$ The term 'modern state' is here employed as a heuristic term denoting a number of elements that have increasingly shaped both normative understandings of the state and actual state practices from about the eighteenth century onwards (for an elaboration see Kraler 2009: 110f).

${ }^{3}$ The implicit parallel of Hobbes ' Leviathan and the description of population with statistics is drawn from Reinprecht 2010.

${ }^{4}$ Statistical representations thus can similarly be seen as what John Searle described as 'institutional facts' - facts that are created by performative acts such as legal decisions or statistical procedures (See Searle 1995).

${ }^{5}$ Authors' translation.
} 
marker of difference within individual polities, reflected again in statistics such as censuses and other statistical records for which information on nationality came to be routinely collected by the late nineteenth century in many European countries. ${ }^{6}$

It was in this period that the first efforts to improve data collection on migration ${ }^{7}$ at an international level were initiated, although at that time largely focused on population movements rather than on stocks of foreign citizens or foreign-born. Reviewing the international efforts to improve data collection on international migration since migration statistics were first tabled as a topic for international harmonisation at the 1891 Congress of the International Statistical Institute in Vienna, two things are remarkable: first, the relatively slow progress achieved over the first 100 years of international efforts to promote the collection of harmonised migration statistics, and secondly, the fast pace in which data collection has changed and expanded in the past 20 years or so, in particular in the European Union (see Herm 2006). While technological developments, notably the emergence and increasing sophistication of computerised data collection systems, are also part of this story and certainly have made data collection, analysis and dissemination much easier, the main driver, we would argue, is the increasing salience of migration as a political issue at the international level after 1989 and the increasing political will to collect comparable data on migration both at the national and the international level and to make resources available to improve data collection.

Importantly, statistics is but one field reflecting this increasing salience of international migration at the international level. Indeed the 1990s saw a veritable surge in the attention paid to migration at the international level (both regional and global), prompting one observer in relation to the UN system to state that "suddenly, migration was everywhere" (Newland 2005: 1). The rise in immigration to industrialised countries, and in particular to Europe, following the collapse of Communist regimes in the Eastern Bloc countries, as well as growing numbers of migrants from countries in the global South, have been important drivers for the Europeanisation of policy debates and policymaking on migration in the European context. This has led to various efforts at harmonising asylum policies from the late 1980s onwards, even before migration policy officially became an issue of European Union policymaking. The establishment of the Schengen system by a group of like-minded European states in 1985 and its subsequent communitarisation through the Amsterdam Treaty (1997) was also an important stimulus for the Europeanisation of migration policies and the Europeanisation of knowledge production on migration associated with it. On the global level the internationalisation of debates on migration is reflected, amongst others, by the relaunch in 1989 of the Intergovernmental Committee for

\footnotetext{
${ }^{6}$ However, nationality also competed with other categories of difference (cf. Kraler 2010: 106f). For example, in the Austrian-Hungarian monarchy, language community/ethnicity or local right to residence (Heimatrecht) remained crucial status categories in the Austrian half, reflecting the incomplete homogenisation of territorial rule in the Habsburg empire.

${ }^{7}$ Throughout this chapter, we use migration to refer to international migration for the sake of simplicity, except where otherwise noted.
} 
Migration (ICM) as the International Organization for Migration (IOM). Since then IOM has repositioned itself as an expert organisation, while policy-oriented research has become a core element of its activities, epitomised in the concept of 'migration management' that was popularised by IOM's senior consultant Bimal Ghosh (Georgi 2010: 54-56). Another indication of this development is the massive growth of the office of the United Nations High Commissioner for Refugees (UNHCR) in the 1990s and its increasing engagement in knowledge production on migration more generally. Other elements include the creation of new regional organisations focused on migration such as the International Centre for Migration Policy Development (ICMPD). ${ }^{8}$ Migration also came to play a more prominent role in existing international organisations such as the Council of Europe and the Organisation for Economic Cooperation and Development (OECD). Furthermore, various regional processes focused on migration have been launched, such as the Intergovernmental Consultations on Immigration and Asylum (IGC), founded in 1987, or the Budapest Process, established in 1993. Various global consultation mechanisms on migration have also been established, for example the UN High Level Dialogues on Migration and Development or the Global Forum on Migration and Development. Though framed in terms of migration and development, both are primarily and to a large extent about migration as such (see Kraler 2014). The internationalisation of political debates on migration has massively contributed to the surge in knowledge production on this topic from a global perspective. This has been a major driver for increased efforts to collect comparable and more extensive statistical data on migration not only worldwide, but also at the European level.

In the European Union an additional driver for the institutionalisation of data collection on migration and the development of a specific policy for migration statistics derives from the the EU's knowledge-driven mode of governance, as reflected and acknowledged in the European Commission's White Paper on Governance (Commission of the European Communities 2001b) and in a subsequent Communication on the collection and use of expertise by the Commission (Commission of the European Communities 2002). Not unlike other international organisations, technocratic rationality arguably lies at the heart of EU policymaking. What distinguishes the European Union from most other international organisations is its regulatory power and related quest for legitimacy, articulated also in its complex institutional structures and governance procedures. Given its still limited parliamentary legitimacy (despite the changes following the Lisbon Treaty) and its problematic 'indirect legitimacy', ${ }^{9}$ technocratic and procedural legitimacy arguably

\footnotetext{
${ }^{8}$ ICMPD was founded in 1993 on the initiative of Austria and Switzerland in the context of the massive changes of migration patterns after 1989, the perception of an asylum crisis in the early 1990s, and the crisis of displacement in the Western Balkans. Beyond these immediate concerns, a major impetus for the establishment of the organisation was the increasing political demand for expert advice on migration issues, a factor also relevant for the establishment of academic migration research institutes.

${ }^{9}$ Indirect legitimacy refers to the legitimacy deriving from the sovereignty (and democratic legitimacy) of its component states (Lord and Magnette 2004: 185). Indirect legitimacy is
} 
are the EU's main sources of legitimacy, with both sources stressing a particular kind of rationality and relying on particular types of expertise. Indeed, in a regulatory system like the EU it is to a large extent knowledge rather than budget that is the critical resource in policymaking (Majone 1996, quoted in Radaelli 1999: 759). While (scientific) knowledge that can provide such technocratic legitimacy need not be quantifiable, quantitative knowledge arguably has a much greater persuasive power than narrative knowledge, as numbers convey a sense of authority and objectivity that more qualitative forms of knowledge fail to convey (Espeland and Stevens 2009: 416-422). There is also a peculiar aesthetics around numbers and their capacity to condense complex social phenomena into individual, easily comprehensible indicators. The surge of knowledge production on migration in and by the European Union has to be understood in this context (see also Boswell 2009). It is this story that will be the focus of this chapter.

The remainder of this chapter is structured as follows: in the next part we will provide a brief history of data collection on international migration in Europe. A major focus in this part will be on the evolution of the Statistics Regulation (Regulation (EC) No 862/2007), which is arguably one of the cornerstones of migration statistics policy in the EU. In the part that follows we will discuss the use of migration-related data in Europe for international comparative research with a focus on the categories used in statistics to identify migrant populations and the usefulness of social indicators for migration policymaking. In the final part of this chapter we will see that, though social indicators may be very useful for comparative research, certain limitations exist when it comes to comparing concrete policies and their effectiveness. This is not only because certain differences in definitions and data collection tend to persist, but also because the major political responsibilities for migrant integration, the main theme of this book, still rest with the member states, and not with the EU. Notwithstanding considerable efforts by the EU to achieve more coordination in the field of immigrant integration member states continue to differ significantly in their approaches to this issue.

\subsection{The Politics of Harmonising International Migration Statistics}

Migration and related efforts to harmonise international data collection on migration have been on the agenda of population statistics since it was institutionalised as a field of data collection and research in the nineteenth century, often closely

problematic in different regards. The legitimacy of EU policies is problematised by member state policymakers themselves whether more generally or in regard to specific policies (to which they may have consented or not). Indirect legitimacy can be seen as problematic in the context of the expansion of majority voting and the fact that it is underlying procedural rules, rather than particular policies, which are legitimised by member states' consent. 
linked to wider political projects. In 1843, for instance, participants of the General Conference of the German Customs Union grappled with the problem of how to deal with temporary residence in the territory of the Union and discussed at great length who should be considered as belonging to the ordinary resident population, in the aim of harmonising definitions within the (German) member states of the Union (Schmidt 2005: 133). At a truly international level, migration statistics were first discussed at the 1891 congress of the International Statistical Institute in Vienna. The first attempts to standardise definitions in migration statistics followed 30 years later at the International Conference on Emigration and Immigration in Rome in 1924. This conference was followed by several conferences each adopting resolutions on migration statistics. Institutionally, the International Labour Organisation (ILO), created in 1919, became the main actor in regard to promoting efforts to improve international data collection on migration, albeit seeing migration mainly as an issue of manpower and labour rather than one of population.

An ILO-sponsored conference on migration statistics in 1932 adopted the first more systematic set of recommendations for the improvement of migration statistics (United Nations 1949: 1). From the outset, achieving comparable international migration statistics was considered important not only for statistical, or for that matter, scientific, purposes; it was also seen as a precondition for ' $\ldots$ the regulation of migration by international convention' [and a tool to] 'facilitate cooperation of the administrative authorities of different countries' (International Labour Office 1932: 86, quoted in Kraly and Gnanasekaran 1987: 968). The 1932 recommendations were revised in 1953 and 1976, but both times not widely implemented. The latest revision dates from 1997 (Herm 2006; United Nations 1998). It was preceded by several conferences and studies, also drawing on expertise from outside the UN system such as the Council of Europe, the OECD,${ }^{10}$ IOM and Eurostat, all of which had become key players in policies on statistical data collection by the time of the 1997 revision, with the role played by Eurostat reflecting the increasing weight of the European Union at the international level more generally (Herm 2006).

\subsubsection{Policies on Collection of Migration Statistics in the European Union}

Efforts at collecting data on migration at the European level extend back to the mid1970s and the ill-fated Community Regulation (EEC) No 311/76 on the compilation of statistics on foreign workers. The latter required member states to supply annual statistics both on the number of workers and on their first employment, without, however, providing guidelines on definitions or data sources to be used. This

\footnotetext{
${ }^{10}$ The OECD has been involved in collecting, disseminating and improving the harmonisation of international migration statistics since the establishment of SOPEMI (Système d'Observation Permanente sur les Migrations) in 1973.
} 
resulted in a potpourri of incomplete and incomparable data, of little use for either policymaking or research. By the late 1980s, Eurostat engaged in renewed efforts to collect basic data on migration and commissioned a number of studies about data collection on migration in the member states of the then European Community, subsequently further extended to European Free Trade Association member states. These studies resulted in a set of tables agreed by member states and Eurostat as a basis for future data collection on migration. A programme for the collection of statistics on international migration was subsequently launched in 1992, and, in the mid-1990s linked to a joint data collection programme run in cooperation with the United Nations Economic Commission for Europe (UNECE), and later also joined by the UN Statistical Division (UNSD), the Council of Europe (CoE) and the International Labour Office (ILO). In 1994 a first publication presenting data on migration flows and stocks based on these new data collection programmes was launched. Data and limited methodological information were also included in Eurostat's statistical database New Cronos. Data collection, however, remained voluntary, incomplete and inconsistent, and doubtful in terms of the reliability of the data included in the dataset (Herm 2006: 93-95).

The nascent cooperation of EU member states on migration and asylum initiated by the Maastricht Treaty (although to some extent actually preceding it) gave rise to separate data being collected through two Council working groups, respectively on irregular migration (the Centre for Information, Discussion and Exchange on the Crossing of Frontiers and Immigration, CIREFI) and asylum (the Centre for Information, Discussion and Exchange on Asylum, CIREA), both established in the mid-1990s. Following the communitarisation of policies on migration and asylum through the Amsterdam Treaty, and responding to the conclusions of the Justice and Home Affairs Council of 1998 ("Vienna Action Plan"), which called for an improvement of the exchange of statistics and information on asylum, data collection was conducted on a more systematic basis from 1998. Responsibility for collecting data was then handed over from the Council Secretariat to Eurostat (Commission of the European Communities 2001a: 4-5). Before 2004 the data were only partly accessible to the public due to member states' concerns about the confidentiality and sensitivity of data on irregular migration, and about their problematic quality. Nevertheless the development of migration statistics policy at the EU level was arguably pushed by member states' interest in statistics directly concerned with migration control, rather than their interest in general demographic data on migration. Tellingly, a Commission Action Plan for the collection and analysis of Community statistics drafted in response to the conclusions of the Laeken Council in 2001, which called for increased efforts to collect comparable statistical data, is most concrete and elaborate in regard to data on asylum and irregular migration, but almost silent on legal migration or migration defined in demographic terms. Implicitly this suggests that the Action Plan simply proposes to carry over Eurostat's data collection on general demographic indicators on migration initiated in 1998 into a legally regulated regime under future Community legislation (see Commission of the European Communities 2003). 
Both the demographic data collection initiated by Eurostat and the data collection on irregular migration and asylum originally initiated and implemented by the Council have been relatively little used. This is because of the limitations of the data collected and the restrictions placed on their public dissemination, but also because a particular policy purpose has been lacking. If they have been used at all, it has been as simple indicators of the size and development of particular target populations, but not for more complex analytical purposes, policy development or policy evaluation. Thus, while the commitment to 'evidence-based policymaking' was a strong factor in further developing data collection, the statistical information produced hardly seemed to matter to policymaking initially, as was the case also with the information collected by the European Migration Network launched around the same time (on the EMN see Boswell 2009).

By contrast, reforms to the collection of social statistics, largely absent from European efforts to improve data collection on migration before the mid-2000s, followed a decisively different path. Linked to the introduction of the Open Method of Coordination (OMC) ${ }^{11}$ as a new mode of governance, social statistics became understood as (quantitative) benchmarks of national initiatives and performance indicators (Bruno et al. 2006). To this end a set of indicators - the so-called Laeken indicators for social inclusion - were defined in 2001. Information was to be collected through the European Union Statistics on Income and Living Conditions (EU-SILC) as of 2003, ${ }^{12}$ and complemented by a set of structural indicators drawn from various data-sources, including the EU Labour Force Survey with regard to basic employment indicators. While these datasets in theory - and at least to a limited extent - would have facilitated the monitoring of social and employment indicators in relation to migrants from the early 2000s, 10 years had elapsed before relevant data came to be systematically used at the EU level to monitor the integration of immigrants in the form of institutionalised integration monitoring (see below).

The development of EU policies on migration statistics relied heavily on the mobilisation of 'external' expertise. The mobilisation of expertise helped to create an 'epistemic community' (Haas 1992) ${ }^{13}$ involving policymakers, academics

\footnotetext{
${ }^{11}$ The OMC was proposed at the 2000 Council Summit in Lisbon (see http://www.europarl.europa. eu/summits/lis1_en.htm, accessed 20 September 2012) and re-endorsed in 2008 (see Commission of the European Communities 2008).

${ }^{12} \mathrm{EU}-\mathrm{SILC}$ is an EU-wide harmonised sample survey which collects comprehensive data on social issues, including indicators on poverty and social exclusion (Regulation (EC) No 1177/2003 concerning Community statistics on income and living conditions (EU-SILC)). EU-SILC replaced the earlier European Household Panel.

${ }^{13}$ The contemporary use of the term goes back to P.M. Haas (1992), who developed the concept in the context of environmental and climate policies. The term itself is older, and has been used by earlier writers, although in a more limited meaning. P.M. Haas' use of the term explicitly takes up the notion of "thought collective" developed by German sociologist Ludwig Fleck in the 1930s. According to Haas (1992: 3), "[a]n epistemic community is a network of professionals with recognized expertise and competence in a particular domain and an authoritative claim to policyrelevant knowledge within that domain or issue-area". These professionals share a set of normative
} 
based at universities and research institutions, statistical institutes and international organisations, sharing a common vocabulary, a common belief in the need to produce comparable statistics, and a common understanding of related challenges. Throughout the 1990s and 2000s, Eurostat commissioned several studies contributing to its data collection efforts. In the mid-1990s, joint meetings on migration statistics were initiated by Eurostat and UNECE, largely drawing on their own expertise and those of national statistical institutes, but also regularly inviting external experts from academic institutions or international organisations (see Herm 2006). Commissioned research and regular meetings were important instruments for creating a like-minded community of experts. In addition, circulation of experts in the form of posting of national statistical experts at Eurostat or UNECE or career trajectories of individuals spanning both spates of service in public office and academia, etc. - were important drivers as well.

In addition, several research projects were funded under the EU's 5th and 6th Framework Programmes for Research ${ }^{14}$ thus contributing to the development of a legal framework for the collection of migration statistics at the EU level. The adoption by the member states of the 'Regulation on Community Statistics on Migration and International Protection' (Regulation 862/2007) in July 2007, first presented as a legislative proposal in September 2005, can be considered a major turning point in EU policies on data collection for migration and asylum.

Reflecting the growing importance of migration issues at the EU level, Regulation 862/2007 breaks with the 'gentlemen's agreement' approach to voluntary data collection by EU member states on issues concerning migration and asylum. Furthermore it provides for mandatory and harmonised statistical data collection on core demographic indicators as well as on key indicators concerning the management of migration. The regulation covers the provision of comprehensive data based on harmonised definitions of population by citizenship and country of birth, migration movements, acquisition and loss of citizenship, asylum, residence permits as well as enforcement of immigration legislation. In an effort to create an incentive for providing accurate data, the allocation of various EU funds on migration and asylum was linked to data collected in compliance with Regulation 862/2007 (Kraler et al. 2006: 70).

While the optional collection of socio-demographic data suggested by the European Commission in earlier drafts of Regulation (EC) No 862/2007 was removed during negotiations, statistical data on migrants' socio-demographic characteristics has seen an enormous expansion through other EU mechanisms. It now also involves quasi-mandatory elements, for example in the framework of European surveys such

and principled beliefs, causal beliefs, and notions of validity, and are engaged in a common policy enterprise.

${ }^{14}$ These included the projects COMPSTAT (Comparing National Data Sources in the Field of Migration and Integration), THESIM (Towards Harmonised European Statistics on International Migration) and PROMINSTAT (Promoting Comparative Quantitative Research in the Field of Migration and Integration in Europe). 
as the Labour Force Survey (EU-LFS) (notably through its 2008 ad hoc module on migrants in the labour market, repeated in 2014). In addition, in 2008, Regulation (EC) No 763/2008 on Population and Housing Censuses was adopted, stipulating obligatory topics for population and housing censuses for the reference year 2011 and including core information related to migration, most notably information on country of birth, country of citizenship and other basic data related to migration.

Since the implementation of the Regulation 862/2007, statistics, particularly those related to migration enforcement and asylum, have been increasingly used as performance indicators, notably to derive recognition rates from asylum statistics or to calculate ratios between return decisions and actual returns. Ten years after the Lisbon strategy was adopted, social indicators on migrants, as noted above, came to be systematically collected in the form of 'indicators of migrant integration', to be used for 'monitoring the results of integration policies in order to increase the comparability of national experiences and reinforce the European learning process' (European Council 2010). The need to evaluate integration policies through indicators has been put forward several times since the Hague programme, adopted by the Council in 2004, while in the Stockholm programme of 2009 the explicit call for the development of indicators of migrant integration was made. This led to the immediate development of indicators by an expert group. Fourteen indicators were developed in the four areas of employment, education, social inclusion and active citizenship, and were endorsed at the Ministerial Conference in Zaragoza in 2010 (European Ministerial Conference on Integration 2010). These indicators were produced in a pilot study by Eurostat (2011) and were subsequently evaluated and tested for their usefulness and robustness.

As a result of these different developments, which in turn were the result of complex discussions involving national data providers, Eurostat, international actors, researchers and policymakers at both the EU and national levels, data availability and accessibility have indeed enormously expanded in the past decades, allowing data users to tap vast and expanding sources of information. Notwithstanding such significant improvements, major deficiencies remain when it comes to availability, comparability and quality of data. The production and analysis of population and migration statistics as well as the institutionalisation of data production and dissemination have always been a concern to representatives of both governance and independent research. Authorities were interested in reliable, comparable data for policymaking but at the same time independent researchers and academia had an interest in using statistics for research, sometimes in order to criticise the authorities. While the adoption of Regulation (EC) No 862/2007 led to an increased availability of harmonised data, major issues are still unsolved in relation to data quality and comparability. It is often unclear what national source data are reported to Eurostat, and how they relate to data published on the national level, an issue of particular concern to administrative data. But also in respect to core demographic data, such as data on migration flows or stocks, data reported to Eurostat still often deviate from agreed data definitions. While availability of data on the European level has indeed much improved, their comparability and quality are still major issues. What is more, the increasing scope and depth of data collection on migration and related areas 
also raises more fundamental issues regarding the meaning (and meaningfulness) of harmonised statistical categories in an expanding European Union, the limits of such harmonisation, and the dangers associated with the use of concepts such as country of birth and citizenship as master frames. These issues will be discussed in the next section.

\subsection{Availability and Comparability of Migration-Related Statistics in Europe}

A major challenge in migration statistics is the insufficient coverage of migrants in available data sources. International migration movements, for example, are often measured through registration data. Due to the fact that people often do not de-register prior to emigrating from a country, emigration is notoriously difficult to capture (cf. Kupiszewska et al. 2010). At the same time, due to the different definitions used in countries, migration data are rarely comparable. Another problem is under-representation of migrants in sample surveys. This is due to several reasons, including a somewhat higher interview refusal rate among migrants. Even more important, however, is the fact that excessively small sample sizes in general population surveys limit the possibilities for quantitative research on migrants. Finally, and probably most importantly, the information included in datasets for identifying migrants varies significantly over different data sources. Register data usually lack comprehensive information as most registers have been built for the purpose of administration and not primarily for statistical analysis. Consequently, only limited information on migrants is available in registers, for example only nationality or only country of birth, but not both. Sufficiently rich datasets can be constructed only when national data collection systems allow for extensive linkage of different registers, as is the case in the Nordic countries. In comparison, surveys have the advantage that they usually contain more information on migration background, but their availability differs across countries.

One potential way to overcome problems with harmonisation and data availability is the extended use of internationally organised sample surveys, in particular the EU-LFS and EU-SILC. However, the need for, and use of different indicators to define migrants or minorities varies greatly between European countries, as will be discussed in the next section.

\subsubsection{Identifying and Defining Migrants - Different Concepts, Needs and Availabilities}

Different historical contexts and experiences of migration are reflected in countries' data collection practices and availability of data (see also Fassmann et al. 2009; Bijl and Verweij 2011). The core information used for identifying migrants in statistical 
datasets is citizenship and country of birth. However, mapping various datasets available for migration research in the EU, migration researchers can differentiate their groups of interest by several characteristics including nationality (citizenship), origin, residence or migration history, legal status, descent and ethnicity (see Table 3.1; cf. Kraler and Reichel 2010: 69-72).

The appropriate choice of indicator for analytical purposes obviously depends on the question to be answered. The concepts shown in Table 3.1 include demographic, sociological and legal categorisations of persons, although clear-cut differentiations are not possible due to the strong association between some of the concepts. For instance, citizenship and legal status measure political membership and the legal situation of persons. Such information is important for citizenship studies, for analysing the impact of legal status on social integration, or for evaluating the composition of immigrants by categories of admission. Origin and residence/migration history provide information on demographic issues, for instance whether a person actually migrated to a country or not. Information on descent and ethnicity are proxies for different sociologically defined concepts of belonging to certain groups. They are strongly related to concepts of race, which are important for investigating issues such as racism and discrimination. Empirically, the choice of an indicator has primarily depended on the availability of data, making citizenship the most commonly used indicator in many European countries. Although citizenship indicates legal membership of a state, it can be used as a proxy for migration history or ethnicity. ${ }^{15}$

When more complex migration research is considered, requiring more precise research questions and better availability of data, the indicators used for defining the population of study need to be more precise as well. Figure 3.1 below gives an overview of the relationship between two core indicators: country of birth and citizenship in Austria in 2007. It shows that $8.6 \%$ of the total population are nonnationals as well as born abroad. An additional $6.3 \%$ of the population have been born abroad (and thus are immigrants) but hold Austrian citizenship. ${ }^{16}$ Thus, in 2007, only about $58 \%$ of all immigrants in Austria were foreign citizens. At the same time, $1.4 \%$ of all persons born in Austria (i.e. non-immigrants) hold foreign citizenship. This percentage is influenced by Austria's lack of ius soli regulations for children born to foreign citizens in Austria.

Figure 3.2 shows the percentage of the foreign population plotted against the foreign-born population in the European Union and Norway. Not surprisingly the two indicators are closely correlated and countries with higher percentages of immigrants also show higher proportions of foreign-born in their population. It

\footnotetext{
${ }^{15}$ Whether citizenship is an appropriate proxy variable depends on the specific context. In countries with a recent history of migration non-citizens may well represent an overwhelming majority of migrants; in countries with a longer migration history, a colonial legacy and/or very liberal policies on citizenship acquisition, foreign nationals may, by contrast, only represent a fraction of the total population of immigrants defined by country of birth.

${ }^{16}$ The majority of this group are naturalised citizens, since there is only a small number of persons born abroad as Austrians who move to Austria at a later stage.
} 


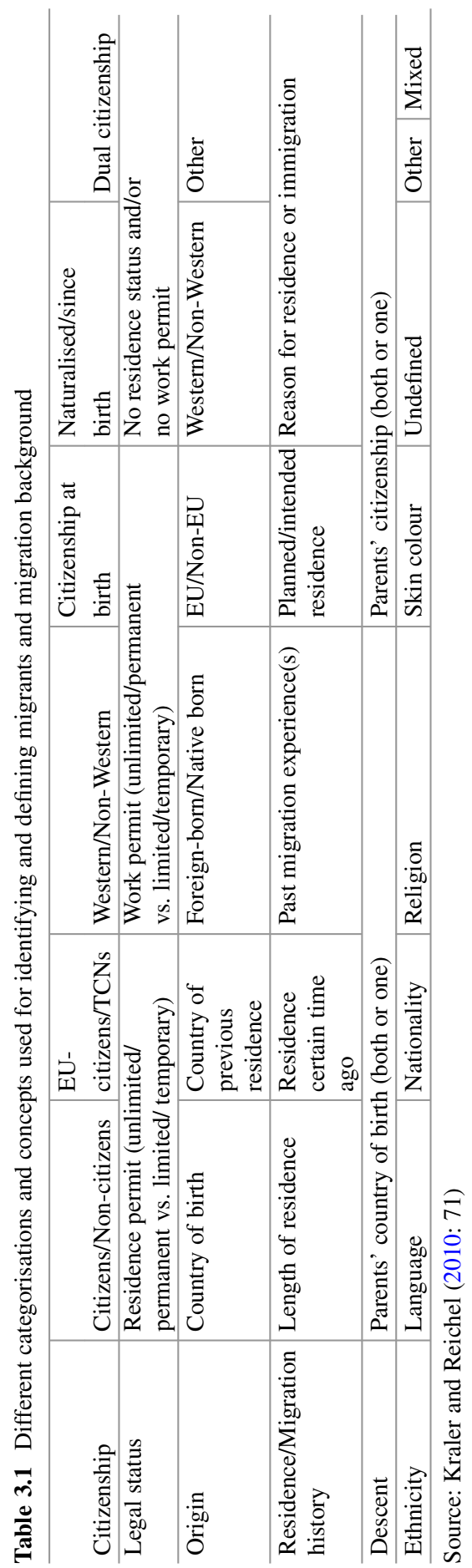


Fig. 3.1 The two main indicators compared: foreign-born and foreign nationals in Austria (2007) (Source: own presentation based on data from Statistics Austria)

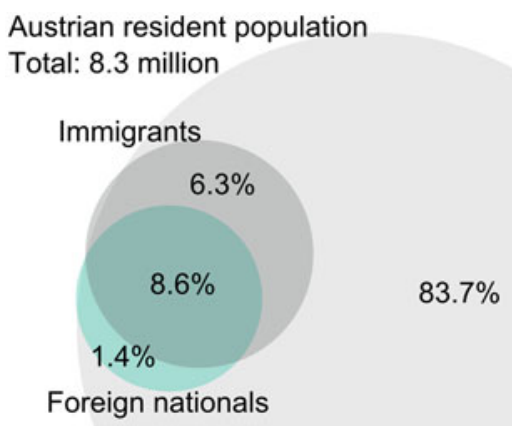

Austrian resident population

Total: 8.3 million

is however important to highlight the apparently small but significant differences between the two indicators. Not all foreigners are foreign-born and not all foreignborn persons are foreigners (e.g. immigrants who were not foreign citizens at the time of immigration or who acquired citizenship after immigration). This difference can mainly be explained by different practices of naturalisation and citizenship policies. Figure 3.2 shows that there is a clear tendency towards higher percentages of foreign-born compared to foreign citizens (the data points tend towards the lower right panel). This difference is influenced by naturalisation rates in the countries, which are affected by naturalisation policies (cf. Reichel 2011, 2012).

Ultimately, however, the particular questions at stake should guide the use of indicators, whether citizenship, country of birth or 'foreign background'. The latter variable was first collected systematically across a large number of EU member states in the 2008 ad-hoc module of the EU-LFS on migrants in the labour market, and usually refers to residents with both parents born abroad, thus including not only the first, but also the 'second migrant generation'. The - at least theoretical availability of different indicators to identify migrant populations also is a useful reminder that 'migrant' is an essentially fluid, contingent and historically variable concept. No matter how it is defined, it does not identify a certain population with immutable traits. Instead it reflects statistical concepts such as country of birth or citizenship that differentiate populations according to certain attributes, e.g. holding the citizenship of another country or having been born in another country. In themselves these attributes mean little. What is more, grasping the importance of international mobility for individuals may require quite different indicators to those regularly collected, including migration experiences of the native population. In a context where international mobility increasingly forms part of the life course, be it for study purposes, employment, family or other reasons, more complex indicators 


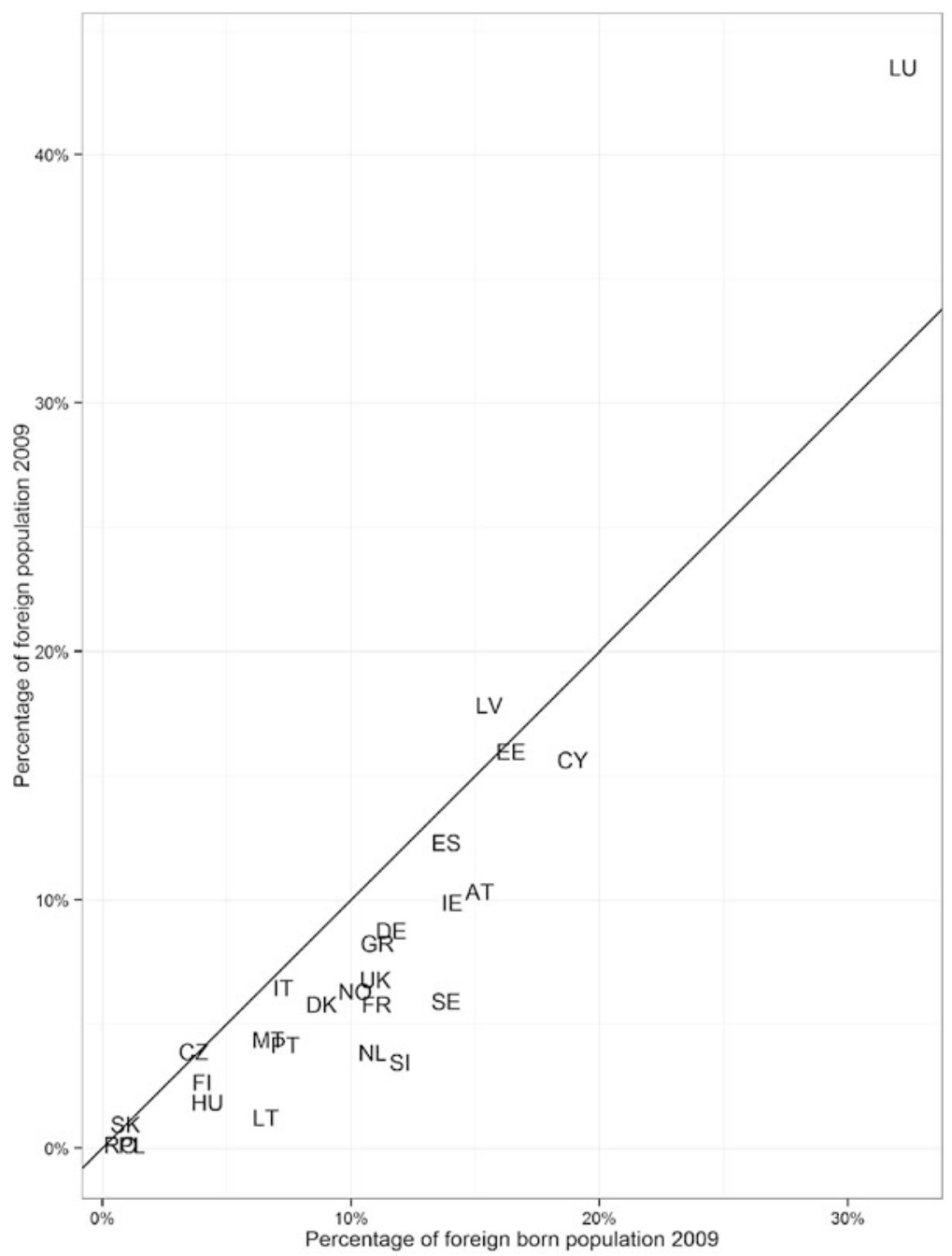

Fig. 3.2 The two main indicators compared: percentages of foreign-born and foreign nationals in the European Union and Norway (2009) (Source: Eurostat database, Migration Statistics. Data for Belgium and Bulgaria are missing)

may well be needed. In the final analysis, however, a flexible use of indicators is required rather than a fixation on particular categories identifying particular segments of the population. While perhaps cumbersome, the allusions of sameness and difference conveyed by statistical indicators and discussed in the introductory section of this chapter need to be regarded as an obstacle to knowledge production on migration, rather than as a facilitator. 


\subsubsection{The Effect of Policy Differences}

With our earlier observation that the share of foreign citizens residing in a country depends not only on past immigration levels, but also on policies regarding naturalisation we touched upon an aspect in immigration research that complicates comparisons even further. While it is true that agreements have been reached in the European Union on the definition of some of the major concepts that relate to the process of migration - albeit after long deliberation - it has proved to be much more difficult to arrive at some common standards on how to measure immigrant integration (see also Chap. 7). This can be explained to a large extent by the fact that European countries differ significantly in their views on how concepts such as integration and social cohesion should be understood and on what role public policy should play in facilitating such processes. This is not the place to elaborate on differences in objectives that countries may define for their integration policies (see, for example, Scholten 2011), but it requires little effort to understand that a policy of multiculturalism requires data that differ from those needed when policies are oriented more to assimilation. In the former case, for example, governments may wish to know how many children attend classes in mother tongue teaching, whilst in the latter case they will be more interested in knowing how many are fluent in the national language.

In the foreseeable future it is not very likely that consensus will be reached at a European level on a definition of immigrant integration and on the indicators used to measure it and to assess the effectiveness of relevant policy instruments beyond the limited - and ambiguous - Zaragoza indicators (see Eurostat 2011). Certain oft-used indicators are not always as clear-cut as they may seem. Segregated housing, for example, is usually seen as the outcome of unfair selection processes and discrimination, and therefore as reflecting a lack of integration. But what if members of a migrant community deliberately choose to live close to co-ethnics or co-nationals, a choice that automatically leads to concentration and, as a logical consequence, to segregation of other communities? And what if a high frequency of contacts with the home country is seen as a sign of lacking integration, as is often the case, while in reality research has shown that migrants with frequent transnational contacts also maintain frequent contacts in their country of residence, usually taken as a sign of integration (Snel et al. 2006)? Thus, one has to be very careful in interpreting immigrant behaviour and in drawing conclusions from it concerning their integration. That commonly used indicators can be interpreted in such different ways makes it extremely challenging to achieve consensus on how the process of immigrant integration should be understood and measured in a comparative perspective.

A final question that arises in comparative research on immigrant integration has to do with reference groups and benchmarks. The following example may clarify this point. Labour force participation among immigrants is generally seen as a reliable indicator for their integration. Now take an immigrant community, say the Turks, which in country A has a labour force participation rate of $70 \%$, while the 
overall participation rate in that country is $80 \%$. Then take country $\mathrm{B}$, where the Turkish participation rate is $60 \%$, while total labour force participation also stands at $60 \%$. In which of these two countries can Turks be seen as better integrated? If we take the total participation rate as a benchmark, the answer would be country $\mathrm{B}$, since the Turkish community and the entire population participate at exactly the same level. However, seen from the perspective of the Turkish community, integration in country A would be more successful, as their participation level is ten percentage points higher there than it is in country A, in spite of the fact that it is below the overall average for that country. The more general question here is: what should be the reference group in comparative research on immigrant integration and in assessing the effects of integration policies? Should it be the same community in different countries, or should it be different communities in the same country? The example just given makes clear that even when comparable data are available conclusions may differ vastly, depending on the questions asked and the methodological choices made.

\subsection{Conclusions}

The collection of migration statistics has always been an important component of official statistics and population research, which is also reflected in the close involvement of academics and public administrators in the process of data collection and analysis. In particular, the efforts of the European Union have led to considerable expansion of available data in the area of migration, notably through the adoption of Regulation (EC) No 862/2007 which made it compulsory for EU member states to provide Eurostat with comprehensive data on migration issues.

The increased availability of international data in the area of migration has led to an enormous expansion of opportunities for research, and the full potential of Eurostat's newly collected data is still to be exhausted. However, on the conceptual level, several questions remain. In particular, the institutionalisation of certain demographic indicators, notably country of birth, begs the question as to how useful these concepts are and whether they need to be complemented by additional indicators which help to identify 'migrants' in a more nuanced and differentiated way. The production and use of social statistics differentiated by 'migration background', be it on the basis of demographic, sociological or ethnic criteria, not only makes these groups visible, but also manifests their very existence and creates a reinforced perception of group differences. As pointed out by Nancy Fraser (2000) we have to be careful when recognising differences within our societies due to the potential effect of reinforcing group identities. Data producers and users, both from policy as well as academia, need to be flexible when dealing with statistics. Yet, this same flexibility, even though it may sometimes be required to cope with the limitations of available data, may also challenge the relevance of the outcomes, particularly in comparative research. This is the case in research on migration, but it is even more so in research on immigrant integration and the effectiveness 
of integration policies. Here significant differences in objectives and instruments persist between European countries, thus creating even more ambiguity in the use of statistics and their interpretation.

Open Access This chapter is distributed under the terms of the Creative Commons Attribution Noncommercial License, which permits any noncommercial use, distribution, and reproduction in any medium, provided the original author(s) and source are credited.

\section{References}

Bijl, R., \& Verweij, A. (Eds.). (2011). Measuring and monitoring immigrant integration in Europe. The Hague: The Netherlands Institute for Social Research SCP.

Boswell, C. (2009). The political uses of expert knowledge. Immigration policy and social research. Cambridge: Cambridge University Press.

Bruno, I., Jacquot, S., \& Mandin, L. (2006). Europeanization through its instrumentation: benchmarking, mainstreaming and the open method of co-ordination ... toolbox or Pandora's box? Journal of European Public Policy, 13(4), 519-536.

Commission of the European Communities. (2001a). The exchange of statistical information in the field of asylum and migration (Commission staff working paper, $\operatorname{Sec}(2001) 602$ ).

Commission of the European Communities. (2001b). European governance. A white paper $(\operatorname{COM}(2001) 428$ final).

Commission of the European Communities. (2002). Communication from the Commission on the collection and use of expertise by the Commission: Principles and guidelines. "Improving the Knowledge Base for Better Policies" (COM(2002) 713 final).

Commission of the European Communities. (2003). Communication from the Commission to the Council and the European Parliament to present an action plan for the collection and analysis of Community Statistics in the field of migration (COM(2003) 179 final).

Commission of the European Communities. (2008). Communication from the Commission to the Council, the European Parliament, the European Social and Economic Committee and the Committee of the Regions. 'A renewed commitment to social Europe: Reinforcing the Open Method of Coordination for Social Protection and Social Inclusion' (COM(2008) 418 final).

Espeland, W. N., \& Stevens, M. L. (2009). Sociology of quantification. European Journal of Sociology, 49(3), 401-436.

European Council. (2010). The Stockholm Programme - An open and secure Europe serving and protecting citizens. Official Journal of the European Union, 2010/C 115/01.

European Ministerial Conference on Integration. (2010, April 15 and 16). Draft declaration. Zaragoza. http://ec.europa.eu/ewsi/UDRW/images/items/docl_13055_519941744.pdf. Accessed 21 Jan 2015.

Eurostat. (2011). Indicators of immigrant integration - A pilot study. 2011 edition (Eurostat Methodologies and Working Papers). Luxembourg: Publications Office of the European Union.

Fassmann, H., Reeger, U., \& Sievers, W. (Ed.). (2009). Statistics and reality: Concepts and measurements of migration in Europe. Amsterdam: IMISCOE-Amsterdam University Press.

Fraser, N. (2000, May/June). Rethinking recognition. New Left Review, 3, 107-120.

Georgi, F. (2010). For the benefit of some: The International Organization of Migration and its Global Migration Management. In M. Geiger \& A. Pécoud (Eds.), The politics of international migration management (pp. 45-73). Houndmills: Palgrave Macmillan.

Haas, P. M. (1992). Introduction: Epistemic communities and international policy coordination. International Organization, 46(1), 1-35. 
Hacking, I. (2006). The emergence of probability: A philosophical study of early ideas about probability induction and statistical inference (2nd ed.). Cambridge: Cambridge University Press.

Herm, A. (2006). Recommendations on international migration statistics and development of data collection at an international level. In M. Poulain, N. Perrin, \& A. Singleton (Eds.), THESIM. Towards Harmonised European Statistics on International Migration (pp. 77-106). Louvainla-Neuve: Presses Universitaires de Louvain.

International Labour Office. (1932). Statistics of migration. Definitions - Methods - Classifications (Studies and report series nr. 18). Geneva: International Labour Office.

Kraler, A. (2009). Migration und die Universalisierung der Nationalstaatsform am Beispiel Ruanda. In A. Sonderegger \& A. Kraler (Eds.), Perspectives on ethnicity and 'Race'. Special issue. Stichproben. Wiener Zeitschrift für Kritische Afrikastudien/Vienna Journal of African Studies, 16, 107-142.

Kraler, A. (2010). Globale Migrationen. Migrationsdynamiken seit 1800. In R. Sieder \& E. Langthaler (Eds.), Weltgeschichte 1800 - Gegenwart (pp. 97-132). Wien: Böhlau.

Kraler, A. (2014). Migration und Entwicklung. Interessen, Akteure und Arenen eines erfolgreichen Diskurses. In I. Ataç, M. Fanizadeh, A. Kraler, \& W. Manzenreiter (Eds.), Migration und Entwicklung. Neue Perspektiven (pp. 23-48). Vienna: Promedia.

Kraler, A., \& Reichel, D. (2010). Statistics on migration, integration and discrimination in Europe (PROMINSTAT final report). Vienna: ICMPD.

Kraler, A., Jandl, M., \& Hofmann, M. (2006). The evolution of EU migration policy and implications for data collection. In M. Poulain, N. Perrin, \& A. Singleton (Eds.), THESIM. Towards Harmonised European Statistics on International Migration (pp. 35-75). Louvain-laNeuve: UCL - Presses Universitaires de Louvain.

Kraly, E. P., \& Gnanasekaran, K. S. (1987). Efforts to improve international migration statistics. A historical perspective. International Migration, 21(4), 967-995.

Kupiszewska, D., Kupiszewski, M., Marti, M., \& Ródenas, C. (2010). Possibilities and limitations of comparative quantitative research on international migration flows (Prominstat thematic working paper 4). http://www.prominstat.eu/drupal/?q=node/73. Accessed 2 Jan 2014.

Lord, C., \& Magnette, P. (2004). E Pluribus Unum? Creative disagreement about legitimacy in the EU. Journal of Common Market Studies, 42(1), 183-202.

Majone, G. D. (Ed.). (1996). Regulating Europe. London: Routledge.

Nassehi, A., \& Schroer, M. (1999). Integration durch Staatsbürgerschaft? Einige gesellschaftstheoretische Zweifel. In U. Davy (Ed.), Politische Integration der ausländischen Wohnbevölkerung (pp. 82-104). Baden-Baden: Nomos.

Newland, K. (2005), The governance of international migration: Mechanisms, processes and institutions. A paper prepared for the Policy Analysis and Research Programme of the Global Commission on International Migration. http://www.iom.int/jahia/webdav/site/myjahiasite/ shared/shared/mainsite/policy_and_research/gcim/tp/TS8b.pdf. Accessed 3 Nov 2013.

Radaelli, C. M. (1999). The public policy of the European Union. Whither politics of expertise? Journal of European Public Policy, 6(5), 757-774.

Reichel, D. (2011). Do legal regulations hinder naturalisation? Citizenship policies and naturalisation rates in Europe (EUI working papers. RSCAS 2011/51). http://eudo-citizenship.eu/docs/ RSCAS_2011_51.pdf. Accessed 2 Jan 2014.

Reichel, D. (2012). Regulating political incorporation of immigrants - Naturalisation rates in Europe (ICMPD working paper no. 4). http://research.icmpd.org/fileadmin/Research-Website/ Publications/working_papers/Reichel_Naturalisation_Rates_Europe_2012.pdf. Accessed 15 June 2014.

Reinprecht, C. (2010). Bevölkerungsstruktur, Migration, Lebensformen. In A. Gächter, F. Kolland, P. Dannecker, \& C. Suter (Eds.), Soziologie der globalen Gesellschaft. Eine Einführung (pp. 77-104). Vienna: Mandelbaum.

Schmidt, D. (2005). Statistik und Staatlichkeit. Wiesbaden: VS Verlag für Sozialwissenschaften.

Scholten, P. (2011). Framing immigrant integration. Dutch research-policy dialogues in comparative perspective. Amsterdam: Amsterdam University Press. 
Scott, J. (1998). Seeing like a state. How certain schemes to improve the human condition have failed. Newport: Yale University Press.

Searle, J. (1995). The construction of social reality. London: Penguin.

Snel, E., Engbersen, G., \& Leerkes, A. (2006). Transnational involvement and social integration. Global Networks, 6, 285-308.

United Nations. (1949). Problems of migration statistics (Population studies 5). Lake Success: United Nations.

United Nations. (1998). Recommendations on statistics of international migration. Revision 1. New York: United Nations. 